\title{
Very low mitochondrial variability in a stingless bee endemic to cerrado
}

\author{
Rute Magalhães Brito ${ }^{1,2}$, Flávio de Oliveira Francisco ${ }^{2}$, Elaine Françoso ${ }^{2}$, Leandro Rodrigues Santiago ${ }^{2}$ \\ and Maria Cristina Arias ${ }^{2}$ \\ ${ }^{1}$ Instituto de Genética e Bioquímica, Universidade Federal de Uberlândia, Uberlândia, MG, Brazil. \\ ${ }^{2}$ Departamento de Genética e Biologia Evolutiva, Instituto de Biociências, Universidade de São Paulo, \\ São Paulo, SP, Brazil.
}

\begin{abstract}
Partamona mulata is a stingless bee species endemic to cerrado, a severely threatened phytogeographical domain. Clearing for pasture without proper soil treatment in the cerrado facilitates the proliferation of termite ground nests, which are the nesting sites for $P$. mulata. The genetic consequences of these changes in the cerrado environment for bee populations are still understudied. In this work, we analyzed the genetic diversity of 48 colonies of $P$. mulata collected throughout the species' distribution range by sequencing two mitochondrial genes, cytochrome oxidase I and cytochrome B. A very low polymorphism rate was observed when compared to another Partamona species from the Atlantic forest. Exclusive haplotypes were observed in two of the five areas sampled. The sharing of two haplotypes between collection sites separated by a distance greater than the flight range of queens indicates an ancient distribution for these haplotypes. The low haplotype and nucleotide diversity observed here suggests that $P$. mulata is either a young species or one that has been through population bottlenecks. Locally predominant and exclusive haplotypes $(\mathrm{H} 2$ and $\mathrm{H} 4)$ may have been derived from local remnants through cerrado deforestation and the expansion of a few colonies with abundant nesting sites.
\end{abstract}

Keywords: cerrado, mtDNA, genetic variability, Partamona mulata.

Received: August 16, 2012; Accepted: December 12, 2012.

The land area cleared for pasture in Brazil has increased markedly in the past 40 years and has been driven largely by the beef industry (IBGE, 1974, 2010). Considerable clearance of natural vegetation has occurred in the cerrado. This phytogeographical domain is characterized by a variety of different vegetation physiognomies ranging from grassland to tall woodland, with well-defined seasons that include a very dry season (April to November), when bushfires are common, followed by a humid, rainy season (December to March), when vegetation blossoms (Batalha et al., 2001, 2011). Only $20 \%$ of the original cerrado remains and the endemic vegetation and fauna are under constant threat because of systematic deforestation to provide land for crops or livestock (Myers et al., 2000). Damage to this environment is a threat to bees because it reduces the availability of nesting sites and isolates populations into small fragments and this may lead to inbreeding depression (Kerr et al., 1996). The genetic consequences of these changes for bee populations endemic to the cerrado are still poorly understood.

Habitat fragmentation in the cerrado has been shown to increase inbreeding in populations of the stingless bee

Send correspondence to Rute Magalhães Brito. Avenida Pará 1720 - 2E, sala 246, 38400-902 Uberlândia, MG, Brazil. E-mail: britorm@ingeb.ufu.br.
Melipona rufiventris in Minas Gerais state, Brazil (Tavares et al., 2007). A low genetic variability of microsatellite markers has also been observed in 59 nests of $P$. mulata from five collection sites in cerrado areas of the states of Mato Grosso and Mato Grosso do Sul (Francisco et al., 2006). In the latter case, the microsatellite loci were genotyped using heterospecific primers and the low genetic variability was considered to be an artefact of null alleles rather than a true status for the species.

Although deforestation is usually claimed to be a major cause of reductions in bee populations (Kearns et al., 1998; De la Rúa et al., 2007; Tavares et al., 2007), in the cerrado deforestation together with inadequate soil treatment contributes to the budding of termite ground nests, thereby increasing the availability of nesting sites for Partamona bees. Partamona is a Neotropical stingless bee genus of the tribe Meliponini, distributed from southern Mexico to southern Brazil (Camargo and Pedro, 2003). Except for Partamona helleri, which usually uses abandoned bird nests and epiphyte roots, most Partamona species build their nests in active termite nests. Partamona mulata is a termitophile species endemic to central Brazil (Mato Grosso do Sul and Mato Grosso) and Bolivia and is always associated with ground termite mounds in the cerrado (Pedro and Camargo, 2003). 
The analysis of mitochondrial DNA (mtDNA) polymorphisms is a useful approach for investigating genetic variability and has been successfully applied to studies of insect populations, including Meliponini species (Quezada-Euán et al., 2007; Francisco and Arias, 2010). In this work, we used the polymorphism of two mitochondrial genes to investigate the genetic status of Partamona mulata, a highly endemic cerrado species, and make inferences about the historical events that could explain the observed haplotype distribution.

We analyzed one bee from each of 48 natural nests of $P$. mulata throughout the species' distribution range in cerrado areas of central western Brazil: Cuiabá (Cba; $\mathrm{n}=13$ ), Santo Antônio do Leverger (Sal; $\mathrm{n}=4)$, Poconé (Poc; $\mathrm{n}=13$ ), Cáceres (Cac; $\mathrm{n}=6$ ) and Campo Grande $(\mathrm{Cgd} ; \mathrm{n}=12)$ (Figure 1). The bees were stored at $-80{ }^{\circ} \mathrm{C}$ prior to DNA extraction. All specimens were identified by Dr. Silvia Regina de Menezes Pedro (Faculdade de Filosofia, Ciências e Letras de Ribeirão Preto, USP - FFCLRP/ USP) and voucher specimens were deposited in the collection of the Department of Biology at FFCLRP/USP.

Total DNA was extracted from one thorax per tube using the Chelex $^{\circledR}$ (Bio-Rad) protocol (Walsh et al., 1991). For mtDNA amplification, universal primers for insects (Simon et al., 1994) were used to amplify $451 \mathrm{bp}$ of the cytochrome oxidase I (COI) gene $(\mathrm{mtD} 6+\mathrm{mtD} 9)$ and $402 \mathrm{bp}$ of the cytochrome B $(C y t \mathrm{~B})$ gene $(\mathrm{mtD} 26+\mathrm{mtD} 28)$. $\mathrm{PCR}$ assays were done in a final volume of $50 \mu \mathrm{L}$ containing $4 \mu \mathrm{L}$ of DNA, $5 \mu \mathrm{L}$ of $10 \mathrm{x}$ PCR buffer, $1 \mu \mathrm{L}$ of each primer $(20 \mu \mathrm{M}), 5 \mu \mathrm{L}$ of dNTPs $(2 \mathrm{mM}$ each $), 1.5 \mu \mathrm{L}$ of $50 \mathrm{mM} \mathrm{MgCl}$ and $2.5 \mathrm{U}$ of Taq DNA polymerase (Invitrogen). The PCR cycling conditions were as described elsewhere (Brito and Arias, 2005). Aliquots of the PCR products were run on $1 \%$ agarose gels for quantification, stained with GelRed (Biotium) and photographed under a UV transilluminator. The remaining PCR products were purified by digestion with $0.5 \mu \mathrm{L}$ of ExoSAP-IT ${ }^{\circledR}$ (USB) and sent to Macrogen, South Korea, for sequencing in an automatic sequencer 3730xl (Applied Biosystems, USA). Electropherogram visualization, alignments and concatenation were done using the program Geneious v.5.1.6 (Drummond et al., 2010). The sequences obtained were deposited in GenBank.

Sequences obtained from the $C O I$ (accession numbers: JX480903 to JX480950) and $C y t \mathrm{~B}$ (accession numbers: JX480951 to JX480998) genes were concatenated in an $853 \mathrm{bp}$ sequence for all samples. Haplotypes were analyzed using DnaSP v.5 (Librado and Rozas, 2009) to calculate haplotype diversity $(H d)$ and nucleotide diversity $(\pi)$ (Nei, 1987). Exact tests (Raymond and Rousset, 1995) were calculated using Arlequin v.3.5 (Excoffier and Lischer, 2010) to estimate the genetic differentiation between pairs of populations. A haplotype network was generated by the median-joining network method (Bandelt et al., 1999) using the software Network v.4.5.0.0.

The base composition of the 853 bp concatenated sequences of the $C O \mathrm{I}$ and $C y t \mathrm{~B}$ genes was A: $32.8 \%, \mathrm{C}$ : $14.2 \%$, G: $8.1 \%$ and T: $44.9 \%$. No insertion/deletion (indels) polymorphisms were detected and only three sites were variable, with two transitions and one transversion. Consequently, the average nucleotide diversity was quite low $(\pi=0.00137)$. Two silent mutations were observed in $C y t \mathrm{~B}$ at the third base of codons; only one mutation was observed in $C O$ I. The lower mutation rate in $C O$ I was expected since this gene has higher functional restriction than CytB (Meiklejohn et al., 2007). The mutation in COI oc-

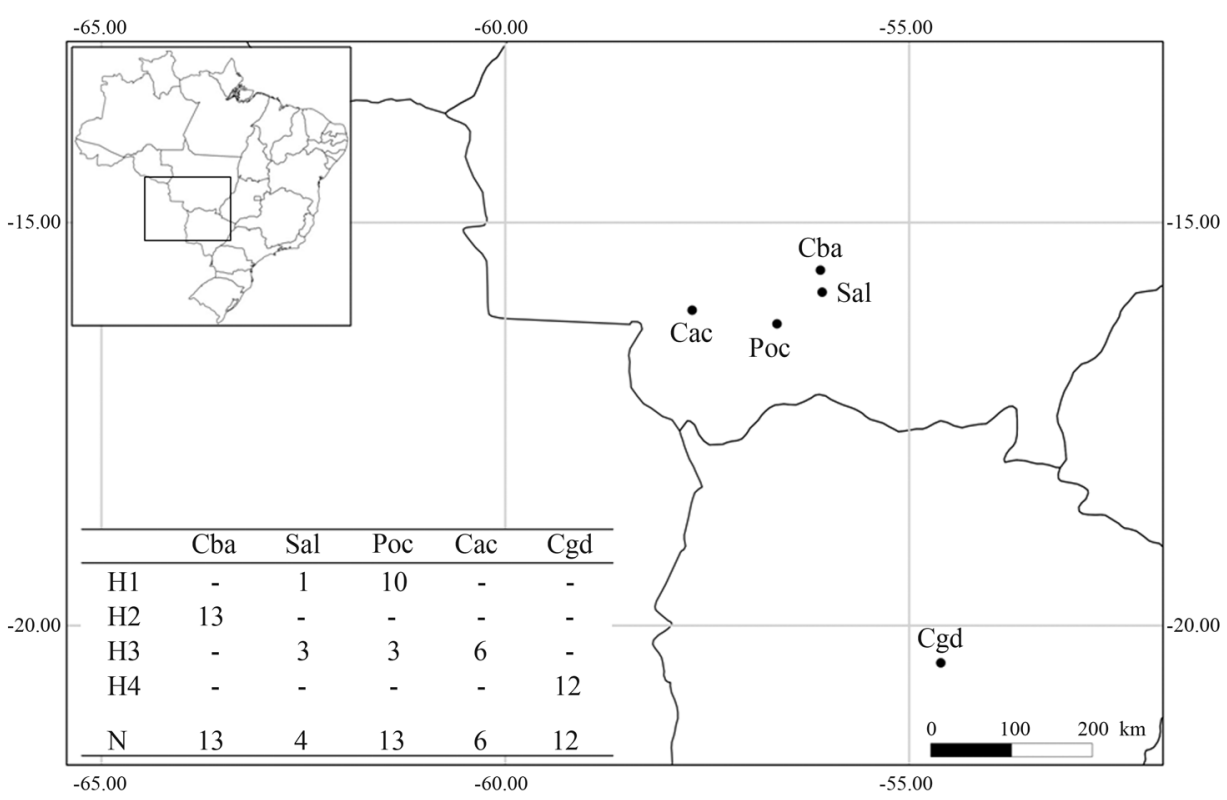

Figure 1 - Collection sites of Partamona mulata in cerrado areas in central Brazil: Cuiabá (Cba), Santo Antônio do Leverger (Sal), Poconé (Poc), Cáceres (Cac) and Campo Grande (Cgd). Haplotype frequencies are shown for each collection site. 
curred at the first position and resulted in a conservative amino acid substitution (Val-Ile), i.e., both amino acids were non-polar and aliphatic.

Only four haplotypes were observed in P. mulata and differed by one or two nucleotide substitutions. Figure 1 shows the haplotype occurrence and sharing between collection sites. Haplotype H1 was shared between Sal and Poc and H3, the most widespread haplotype, occurred at $\mathrm{Sal}, \mathrm{Poc}$ and Cac. Haplotypes $\mathrm{H} 2$ and $\mathrm{H} 4$ were exclusive to the Cba and Cgd collection sites, respectively (Figure 1). Haplotype diversity $(H d)$ calculated for all collection sites together was 0.765 ; for individual collection sites, $H d$ varied from 0.000 , where only one haplotype was observed (Cba, Cac and $\mathrm{Cgd}$ ), to 0.500 (Sal).

Population differentiation values were significant $(p<0.05)$ but exceptions were observed between collection sites $\mathrm{Cac} / \mathrm{Sal}$ and $\mathrm{Poc} / \mathrm{Sal}$. The haplotype network showed $\mathrm{H} 3$ positioned in the centre with all other three haplotypes distant from it by a single mutation step (Figure 2).

Unlike other Meliponini genera that are commercially exploited because of their high quality honey and by-products, Partamona is not harvested and consequently not transported by beekeepers, probably because of this genus's anti-hygienic habit of collecting animal faeces (personal observation). This fact led us to discard the hypothesis that haplotype sharing was due to human interference. In addition, Partamona queens are philopatric, meaning that they do not move more than $300 \mathrm{~m}$ from the maternal nest when they swarm (Wille and Orozco, 1975). Consequently, haplotype sharing by gene flow involving female $P$. mulata is also very unlikely since Poc is $100 \mathrm{~km}$ from Sal and Cac is almost $300 \mathrm{~km}$ from the other two sites (Figure 1).

Haplotype sharing in P. mulata is probably explained by ancient expansion of this species in the cerrado. Palynological and geological records indicate that, in the past, coastal areas of Brazil experienced greater modifications in vegetation cover than the central part of the country $(\mathrm{Ab}$ '

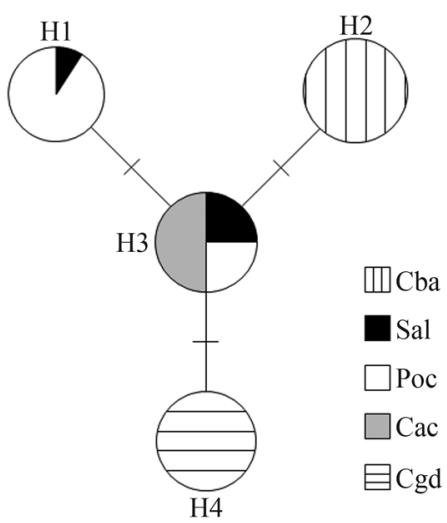

Figure 2 - Media joining network of concatenated partial sequences of the $\mathrm{COI}$ and $\mathrm{Cyt} \mathrm{B}$ mtDNA genes of samples of Partamona mulata showing the relationships among the haplotypes identified in this work. Cac Cáceres, Cba - Cuiabá, Cgd - Campo Grande, Poc - Poconé and Sal - Santo Antônio do Leverger.
Saber, 1979; Carnaval and Moritz, 2008; Carnaval et al., 2009). Thus, while the Atlantic forest contracted and many isolated fragments of vegetation emerged on mountain tops, in cerrado areas woodlands were replaced by grasslands that expanded during cooler periods (Amorim and Pires, 1996).

The low polymorphism rate observed here could be a consequence of small sampling size. However, a study of $P$. helleri that used a similar sample size $(\mathrm{n}=47)$ to ours but a less sensitive marker (PCR-RFLP) identified 10 haplotypes in five sub-populations in the Brazilian Atlantic forest (Brito and Arias, 2010). Since these two species differ markedly in their distribution ranges, with $P$. mulata occupying a smaller area than $P$. helleri (Camargo and Pedro, 2003), a lower polymorphism rate would be expected for $P$. mulata. Other explanations for the low genetic variability observed here include the possibility that $P$. mulata is a young species or that it has experienced population bottlenecks in the recent past. According to Avise (2000), a star-like network is evidence of a species' expansion from a small number of founders. This phenomenon has been reported in natural populations of Hymenoptera, such as the ants Diacamma indicum (Viginier et al., 2004) and Formica cinerea (Goropashnaya et al., 2004) and the bees Bombus insularis (Estoup et al., 1996), Apis cerana (Sihanuntavong et al., 1999) and Melipona rufiventris (Tavares et al., 2007).

Our data suggest that $\mathrm{H} 3$ is the most ancient of the observed haplotypes since it was present at three collection sites and was located in the centre of the network (Figure 2). Population expansion from a center of dispersion and the accumulation of mutations in mtDNA probably gave rise to the other haplotypes. A similar historical pattern has been postulated for stingless bees of the genus Melipona (Tavares et al., 2007; Batalha-Filho et al., 2010) and for the plant species Caryocar brasiliense and Hymenaea stigonocarpa (Collevatti et al., 2003; Ramos et al., 2007). The exclusive haplotypes can also be interpreted as local remnants after bottlenecks. However, given the fact that nucleotide divergence among the four haplotypes was very low, the first explanation seems to be more likely, i.e., dispersion from a central location followed by mutations in mtDNA.

Partamona mulata is currently undergoing successful opportunistic expansion because of the abundance of nesting sites in termite nests. Future samplings over a broader area will be very helpful in understanding the correlation between cerrado degradation and $P$. mulata population expansion, as well as the increase in nest density.

\section{Acknowledgments}

We thank the people who provided information about nest locations and allowed us to collect samples from private farms during sampling expeditions, especially Francisco de Assis Rondon and Mr João Lousano. We also 
thank Susy Coelho for technical support, Silvia Regina de Menezes Pedro (FFCLRP-USP) for identification of the specimens and NIEFA (Núcleo Integrado para Estado da Fauna) for logistical support in Mato Grosso state. This work was supported by FAPESP grants 01/04893-2, 08/08546-4 and 10/50597-5. This work was developed in the Research Center on Biodiversity and Computing, of the Universidade de São Paulo (BioComp).

\section{References}

Ab' Saber AN (1979) Os mecanismos da desintegração das paisagens tropicais no Pleistoceno. Paleoclimas 8:1-11.

Amorim DS and Pires MRS (1996) Neotropical biogeography and method for maximum biodiversity estimation. In: Bicudo CEM and Menezes NA (eds) Biodiversity in Brazil, a First Approach. CNPq, São Paulo, pp 183-219.

Avise JC (2000) Phylogeography: The History and Formation of Species. Harvard University Press, Cambridge, 447 pp.

Bandelt HJ, Forster P and Röhl A (1999) Median-joining networks for inferring intraspecific phylogenies. Mol Biol Evol 16:37-48.

Batalha MA (2011) O cerrado não é um bioma. Biota Neotrop 11:21-24.

Batalha MA, Mantovani W and Mesquita Júnior HN (2001) Vegetation structure in cerrado physiognomies in south-eastern Brazil. Braz J Biol 61:475-483.

Batalha-Filho H, Waldschmidt AM, Campos LAO, Tavares MG and Fernandes-Salomão TM (2010) Phylogeography and historical demography of the neotropical stingless bee Melipona quadrifasciata (Hymenoptera, Apidae): Incongruence between morphology and mitochondrial DNA. Apidologie 41:534-547.

Brito RM and Arias MC (2005) Mitochondrial DNA characterisation of two Partamona species (Hymenoptera, Apidae, Meliponini) by PCR + RFLP and sequencing. Apidologie 36:431-437.

Brito RM and Arias MC (2010) Genetic structure of Partamona helleri (Apidae, Meliponini) from Neotropical Atlantic rainforest. Insectes Soc 57:413-419.

Camargo JMF and Pedro SRM (2003) Meliponini neotropicais: O gênero Partamona Schwarz, 1939 (Hymenoptera, Apidae, Apinae) - Bionomia e biogeografia. Rev Bras Entomol 47:311-372.

Carnaval AC and Moritz C (2008) Historical climate modelling predicts patterns of current biodiversity in the Brazilian Atlantic forest. J Biogeogr 35:1187-1201.

Carnaval AC, Hickerson MJ, Haddad CFB, Rodrigues MT and Moritz C (2009) Stability predicts genetic diversity in the Brazilian Atlantic forest hotspot. Science 323:785-789.

Collevatti RG, Grattapaglia D and Hay JD (2003) Evidences for multiple maternal lineages of Caryocar brasiliense populations in the Brazilian Cerrado based on the analysis of chloroplast DNA sequences and microsatellite haplotype variation. Mol Ecol 12:105-115.

De la Rúa P, May-Itzá WJ, Serrano J and Quezada-Euán JJG (2007) Sequence and RFLP analysis of the ITS2 ribosomal DNA in two Neotropical social bees, Melipona beecheii and Melipona yucatanica (Apidae, Meliponini). Insectes Soc 54:418-423.
Estoup A, Solignac M, Cornuet JM, Goudet J and Scholl A (1996) Genetic differentiation of continental and island populations of Bombus terrestris (Hymenoptera, Apidae) in Europe. Mol Ecol 5:19-31.

Excoffier L and Lischer HEL (2010) Arlequin suite ver. 3.5: A new series of programs to perform population genetics analyses under Linux and Windows. Mol Ecol Resour 10:564567.

Francisco FO and Arias MC (2010) Inferences of evolutionary and ecological events that influenced the population structure of Plebeia remota, a stingless bee from Brazil. Apidologie 41:216-224.

Francisco FO, Brito RM and Arias MC (2006) Allele number and heterozygosity for microsatellite loci in different stingless bee species (Hymenoptera, Apidae, Meliponini). Neotrop Entomol 35:638-643.

Goropashnaya AV, Fedorov VB, Seifert B and Pamilo P (2004) Limited phylogeographical structure across Eurasia in two red wood ant species Formica pratensis and F. lugubris (Hymenoptera, Formicidae). Mol Ecol 13:1849-1858.

Kearns CA, Inouye DW and Waser NM (1998) Endangered mutualisms: The conservation of plant-pollinator interactions. Annu Rev Ecol Syst 29:83-112.

Kerr WE, Carvalho GA and Nascimento VA (1996) Abelha Uruçu - Biologia, Manejo e Conservação. Fundação Acangaú, Belo Horizonte, 144 pp.

Librado P and Rozas J (2009) DnaSP ver. 5: A software for comprehensive analysis of DNA polymorphism data. Bioinformatics 25:1451-1452.

Meiklejohn CD, Montooth KL and Rand DM (2007) Positive and negative selection on the mitochondrial genome. Trends Genet 23:259-263.

Myers N, Mittermeier RA, Mittermeier CG, Fonseca GAB and Kent J (2000) Biodiversity hotspots for conservation priorities. Nature 403:853-858.

Nei M (1987) Molecular Evolutionary Genetics. Columbia University Press, New York, 512 pp.

Pedro SRM and Camargo JMF (2003) Meliponini neotropicais: O gênero Partamona Schwarz, 1939 (Hymenoptera, Apidae). Rev Bras Entomol 47:1-117.

Quezada-Euán JJG, Paxton RJ, Palmer KA, Itzá WJM, Tay WT and Oldroyd BP (2007) Morphological and molecular characters reveal differentiation in a Neotropical social bee, Melipona beecheii (Apidae, Meliponini). Apidologie 38:247-258.

Ramos ACS, Lemos-Filho JP, Ribeiro RA, Santos FR and Lovato MB (2007) Phylogeography of the tree Hymenaea stigonocarpa (Fabaceae, Caesalpinioideae) and the influence of quaternary climate changes in the Brazilian cerrado. Ann Bot-London 100:1219-1228.

Raymond M and Rousset F (1995) An exact test for population differentiation. Evolution 49:1280-1283.

Sihanuntavong D, Sittipraneed S and Klinbunga S (1999) Mitochondrial DNA diversity and population structure of the honey bee, Apis cerana, in Thailand. J Apic Res 38:211-219.

Simon C, Frati F, Beckenbach A, Crespi B, Liu H and Floors P (1994) Evolution, weighting, and phylogenetic utility of mitochondrial gene sequences and a compilation of conserved polymerase chain reaction primers. Ann Entomol Soc Am 87:651-701. 
Tavares MG, Dias LAS, Borges AA, Lopes DM, Busse AHP, Costa RG, Salomão TMF and Campos LAO (2007) Genetic divergence between populations of the stingless bee Uruçu amarela (Melipona rufiventris group, Hymenoptera, Meliponini): Is there a new Melipona species in the Brazilian state of Minas Gerais? Genet Mol Biol 30:667-675.

Viginier B, Peeters C, Brazier L and Doums C (2004) Very low genetic variability in the Indian queenless ant Diacamma indicum. Mol Ecol 13:2095-2100.

Walsh PS, Metzeger DA and Higuchi R (1991) Chelex 100 as a medium for simple extraction of DNA for PCR-based typing from forensic material. Biotechniques 10:506-513.

Wille A and Orozco E (1975) Observations on the founding of a new colony by Trigona cupira (Hymenopterae, Apidae) in Costa Rica. Rev Biol Trop 2:253-287.

\section{Internet Resources}

Arlequin ver. 3.5 Software, http://cmpg.unibe.ch/software/arlequin35/ (August 15th, 2012).
DnaSP ver. 5 Software, http://www.ub.edu/dnasp/ (August 15th, 2012).

Drummond AJ, Ashton B, Buxton S, Cheung M, Cooper A, Duran C, Field M, Heled J, Kearse M, Markowitz S, et al. (2010) Geneious ver. 5.1, http://www.geneious.com/ (August 15th, 2012).

IBGE (1974) Efetivo dos rebanhos por tipo de rebanho, http://www.sidra.ibge.gov.br/bda/tabela/protabl.asp?c $=$ $73 \& \mathrm{z}=\mathrm{t} \& \mathrm{o}=1 \& \mathrm{i}=\mathrm{P}$ (August 15th, 2012).

IBGE (2010) Efetivo dos rebanhos por tipo de rebanho, http://www.sidra.ibge.gov.br/bda/tabela/protabl.asp?c = $73 \& \mathrm{z}=\mathrm{t} \& \mathrm{o}=1 \& \mathrm{i}=\mathrm{P}$ (August 15th, 2012).

National Center for Biotechnology Information - GenBank, http://www.ncbi.nlm.nih.gov/genbank/ (August 15th, 2012).

Network ver. 4.5.0.0. Software, http://www.fluxus-engineering.com (August 15th, 2012).

Associate Editor: Klaus Hartfelder

License information: This is an open-access article distributed under the terms of the Creative Commons Attribution License, which permits unrestricted use, distribution, and reproduction in any medium, provided the original work is properly cited. 